\title{
DIRECT AND CLEAR SUPPORT OF THE EDUCATIONAL INCLUSION
}

\author{
Eva Zezulková
}

Inclusive education is seen as education allowing not only for equal access to education but also for the necessary and adequate support, taking into account the different educational needs of pupils so as to take full advantage of their learning potential. The priority goal of inclusive education is to establish positive conditions for the education of all pupils so that education may be performed preferably by mainstream means. Within the inclusive educational concept, pupils are no longer separated into those with special educational needs and those who do not have such needs but there is only one heterogeneous group of pupils who have individual educational needs. (Lechta, 2010) In inclusive education, the emphasis is primarily laid on a certain degree of support in order to fulfil the expected outputs of education. It does not only take into account the special educational needs of children and pupils, as was the case previously. The so-called support measures reflect the current trends in the field of school education and the purpose of their implementation is to achieve the maximum development of all children and pupils. The term support measures is becoming a key concept in the process of inclusive education. It is a response to a long-discussed necessity for teaching and counselling practice to provide pupils with support measures for the equalization of their difficulties in education. Increased attention will be paid to effective assessment of appropriate support measures to allow for overcoming or mitigating the consequences of the health, social, cultural and other personal disadvantages (Kaleja \& Zezulková, 2016).

Amendments to the Education Act (82/2015 Coll.) defines the support measures and subsequently provides rules for their application in the relevant implementing legislation. The Education Act justifiably mentions as first of the support measures the need for the provision of counselling assistance of schools and school counselling units. The range of services provided by the school counselling staff is wide and mainly depends on the personal composition of the school counselling workplaces. The team of a school counselling centre mostly consists of the teachers authorized for the position of educational counsellors and the school prevention methodology specialist. This model of the school counselling unit is considered as basic. Where the school's possibilities allow, the advanced model of the school counselling unit team also includes a school special needs teacher and a school psychologist (Kucharská et al., 2013). However, the last two occupations mentioned are not represented at most of the schools. The counselling provided directly at schools allow them to provide early educational intervention, which 
has a positive effect on the pupils and students, especially from the perspective of preventing major educational difficulties (Zapletalová \& Mrázková, 2016).

The activities of the school psychologist concentrate on diagnostics and helping pupils in their problems, as well as developing a positive and safe school climate. The involvement of the school special needs teacher is focused on technical support for pupils with special educational needs and all other pupils who need special pedagogical support and care. This support may be based on short-term or long-term support measures. The standard operation of the school psychologist and school special needs teacher is provided for by the regulation 72/2005 Coll., as amended, and divided into screening, diagnostic, consultative, counselling and intervention, methodological, coordinating and educational activities. The activity specification is focused on the methods and expert procedures rather than the content of service provided.

The concept of the project named Direct and clear support of the educational inclusion - the question of school, family, neighbourhood CZ.02.3.61/0.0/0.0/15_007/0000239, currently implemented by the Faculty of Public Policies in Opava, reflects the current needs of teaching praxis to understand the needs of students manifesting school failure risks. It also builds on the results of research investigation in the area of inclusive educational tendencies with substantive intervention into the family environment matters, school environment matter, counselling matters and the competences of teachers and other staff involved in the issues solved'. The objectives of the project are directed toward systematized changes leading to the prevention of school failure.

Due to the thematic focus of this paper, we will continue to pay attention to the selected area of the project purpose, i.e. to extend the activities of the school counselling centre by the position of the school special needs teacher.

In the select schools participating in the project, the new position of the school special needs teacher was created whose job description is in accordance with the applicable legislation and the project purpose. The main objective is to provide educational intervention by means of this position with the prerequisite for effective coordination of educational strategies for the prevention of school failure of the pupils by applying individualized forms of education and individual approach to pupils. The objectives set also predict positive change in favour of inclusive education.

By continuous analysis of the monthly performance reports on the activities of the school special needs teacher, data were collected which are at the same time presented as examples of good practice in counselling services of direct support in schools. The expert services of the special needs teacher provided include:

Screening activities: detecting manifestations of risks in the instruction of pupils, detecting manifestations of risks in the pupils' behaviour, detecting manifestations of risks in the field of language and communication skills in first grade pupils, etc.

\footnotetext{
${ }^{1}$ Kaleja, 2015, 2014; Zezulková, 2015, 2014; Kaleja \& Zezulková et al. 2015; et al.
} 
Diagnostic activities: systematic observation (of students at risk of school failure in the instruction of mathematics, Czech language, English language; of a pupil with Autism Spectrum Disorder (ASD) at risk of school failure in the instruction of the English language and of social studies; pupils with problem behaviour and manifestations of the risk of learning disorders; of a pupil with moderate hearing impairment in the instruction of mathematics, the Czech language and reading, focusing on the efficiency of communication with the teaching assistant; a pupil at increased risk of school failure who was examined at preschool age at a pedagogical psychological counselling office because of suspected reduced intellect; a pupil with medium degree dyslalia; a pupil with developmental dysphasia, etc.); individual screening of school skills in selected pupils (mathematics, reading, language, level of sociability, etc.); analysis of the results of written assignments of students with manifestations of risk in the area of learning potential in the Czech language and mathematics; analysis of the documentation of the school counselling unit (pedagogical-psychological counselling office, hereinafter PPCO, special needs teaching centre, hereinafter SNTC) in order to establish individual educational plans (IEP) for students with developmental dysphasia, for students with mild intellectual disabilities, etc.;

Intervention activities: proposal of plans for pedagogical support (PPPS) for pupils with risk manifestations in behaviour, and pupils at risk of school failure in the instruction of the Czech language, the English language and mathematics; proposals for educational interventions (e.g. due to conflict behaviour of a pupil with ASD); proposals for stimulation programs in the context of home preparation (for pupil with increased risks of school failure); individual pedagogical intervention (for students with low learning potential, pupils with specific learning disorders, pupils with dyslalia, etc.); the teaching of subject of special pedagogical care (for pupils with developmental dysphasia; pupils with ASD, etc.); collective pedagogical intervention (for pupils with pronunciation disorders in the 1 st and 2nd year; for pupils with specific learning disorders on the 2nd level of compulsory schooling, etc.), continuous updates to PPPS and IEP; proposals for individualized forms of instruction in the context of direct support (at the request of teachers of pupils at risk of school failure due to problem behaviour and lower learning potential); proposals of individual approach options (at the request of teachers and classroom assistants of pupils with disabilities, for example ASD or hearing impairment), etc.;

Methodological activities: completion of portfolios (of students with 1st degree supportive measures); procedural schemes of support measures creation; participation in the continuous updates of plans (PPPS, IEP); practical examples of the application of special needs teaching methods (structured learning, visualization, stepping, etc.);

Coordinating activities: consultation with the legal representatives of pupils (on educational and disciplinary issues with recommendations of stimulation home training program, personal consultations with the school psychologist, or if need be, examinations 
at a counselling workplace); consultation with the staff of specialized counselling and other workplaces (e.g. for the purpose of control examination of a pupil with moderate hearing impairment, revisions of and subsequent updates to the support measures for pupils with ASD, etc.); organization of the purchase and registration of special need didactic aids (e.g. educational software for pupils with ASD, aids for the re-education of dyslalia, specific learning disorders (SLD), developmental dysphasia, etc.);

By describing the selected activities of the special needs teacher, we mean to point out the effective possibilities of counselling services in schools for the purpose of timely support and, at the same time, prevention of school failure rates of all pupils. It follows from the stated analysis and the results of the surveys hitherto conducted ${ }^{2}$ that pupils, parents and teachers may be provided with recommendations of the experts of the school counselling units, however, they are more often of a formal nature. Their practical implementation is difficult also because of incomplete staffing of the school counselling workplaces. An important condition of inclusive education is the improvement of counselling services in schools with the permanent participation of a school special needs teacher.

\section{References}

Kaleja, M. (2014). Determinanty edukace sociálně vyloučených žáků z pohledu speciální pedagogiky [Determinants of Education of Socially Excluded Pupils from the Perspective of Special Needs Pedagogy]. 1st Issue. Ostrava: Pedagogical Faculty of Ostrava University in Ostrava.

Kaleja, M., \& Zezulková, E. (2015). Etnografie školy jako edukační realita současnosti [Ethnography of School as the Current Educational Reality]. Opava: The Centre for Empirical Research, Faculty of Public Policies, Silesian University.

Kaleja, M., \& Zezulková, E. (2016). Školská inkluze versus exkluze [School Inclusion Versus Exclusion]. Vybrané kontexty vzdělávání sociálně vyloučených dětí a žákủ s potřebou podpưrných opatření [Selected contexts of the education of socially excluded children and pupils in need of support measures]. Ostrava: Pedagogical Faculty, University of Ostrava.

Kucharská, A. et al. (2013). Školní speciální pedagog [Special Needs Teacher]. Prague: Portál.

Lechta, V. (Ed.). (2016). Základy inkluzívní pedagogiky [The Foundations of Inclusive Education.]. Dítě s postižením, narušením a ohrožením ve škole [The Child with Disability, Disorder and at Risk at School]. Prague: Portál.

\footnotetext{
2 Kaleja, 2015, 2014; Zezulková, 2015, 2014; Kaleja, \& Zezulková et al, 2015 etc.
} 
Zapletalová, J., \& Mrázková, J. (2016). Metodika pro nastavování podpůrných opatření ve školách ve spolupráci se školskými poradenskými zařízeními [Methodology for the Design of Support Measures in Schools in Cooperation with School Counselling Units]. Prague: National Institute for Education.

Zezulková, E. (2015). Vybrané faktory komunikační kompetence žáků v primárním vzdělávání [Selected Factors of Communication Competences of Pupils in Primary Education]. First issue. Opava: Silesian University in Opava.

Zezulková, E., \& Kaleja, M. (2016). Heterogenita žáků základních škol ve speciálněpedagogické diagnostice [Heterogeneity of Primary Schools Pupils in Special Needs Pedagogical Diagnostics]. In: Pedagogická diagnostika a evaluace 2016 [Teaching diagnostics and evaluation of 2016]: Pedagogická diagnostika a evaluace 2016 [Teaching diagnostics and evaluation of 2016] (pp. 15-25). Ostrava: University of Ostrava.

The text is connected with the implemented project Direct and clear support of the educational inclusion - the question of school, family, neighbourhood; a registration number 02.3.61/0.0/0.0/15_007/0000239.

\section{Author}

doc. Mgr. Eva Zezulková, Ph.D.

Faculty of Public Policies, Silesian University in Opava Institute of Pedagogical and Psychological Sciences

Bezručovo nám. 885/14, 74601 Opava, The Czech Republic eva.zezulkova@fvp.slu.cz 